\title{
Visie, Motief, Weë - Geoffrey Wainwright oor die eenheid van die Kerk
}

D J Smit

(UWK/US)

\section{ABSTRACT}

Vision, motive, ways - Geoffrey Wainwright on the unity of the church

Geoffrey Wainwright is without doubt one of the most respected systematic theologians of the century. He has published prolifically and has been involved in major developments in the ecumenical movement. This essay introduces some of the dominant themes in Wainwright's later work. His ecumenical vision of unity-in-truth is discussed (I) Then the reasons motivating this vision are explained, namely to be of praise to the Triune God (2) Finally, the question is asked how Wainwright envisions concrete steps towards this vision. Three issues are discussed, namely his notion of ecumenical spirituality, his respect for common worshop, and his proposals towards mutual confession (3).

\section{Inleidend: Geoffrey Wainwright as ekumeniese teoloog}

Geoffrey Wainwright is sonder enige twyfel een van die mees invloedryke en gerespekteerde sistematiese teoloë binne die ekumeniese beweging. Hy is 'n geordende predikant van die Britse Metodiste Kerk, alhoewel hy sedert 1979 al in die V S A doseer, eers as professor by Union Theological Seminary in New York (1979-1983) en sindsdien as professor by Duke University, Durham, NC. Hy studeer in Cambridge, Geneve en Rome en het doktorsgrade van eersgenoemde twee verwerf. Hy is jarelange lid van die Faith and Order-komitee van die Wêreldraad van Kerke en was voorsitter van die skryfgroep wat die uiters belangrike Lima-konsensus-teks, Baptism, eucharist and ministry (1982) opgestel het. Daarby was hy intens betrokke by verskeie bilaterale en multilaterale gesprekke tussen konfessionele wêreldliggame, waar onder die Joint Commission between the World Methodist Council and the Roman Catholic Church, waarvan hy sedert 1986 die mede-voorsitter is. Hy was reeds president van die internasionale Societas Liturgica (1983-1985) en die American Theological Society (1996-1997). Hy het reeds regoor die wêreld lesings gegee en sy werk is gepubliseer, vertaal en bekend in talle tale. In Mei 1999 besoek hy Suid-Afrika vir die eerste maal, as besoekende navorser.

Hy is die skrywer en mede-skrywer van talle gesaghebbende werke, wat ook in Suid-Afrika goed bekend is. Onder die bekendstes - uit onge- 
veer 270 titels - tel sy epogmakende bydrae tot die twintigste eeuse herwinning van die eskatologiese element in die nagmaal, Eucharist and eschatology (1981b) en sy ewe vernuwende dogmatiek vanuit liturgiese perspektief, Doxology (1980a). Van die bekendste woordeboeke en ensiklopedieë waarvan hy mede-redakteur was, en waarin hy telkens sleutelbydraes self geskryf het, sluit in The study of liturgy (met C Jones en E Yarnold, 1992a), The study of spirituality (eweneens met Jones en Yarnold, 1986a), Ordination rites past and present en Liturgical time (albei met Wiebe Vos, onderskeidelik 1980 b en 1982c) en veral die imposante Dictionary of the ecumenical movement (met N Lossky en andere, 1991b, hersiene uitgawe 1999). Rondom die Lima-dokument was hy die (mede-) redakteur van Baptism and eucharist: Ecumenical convergence in celebration (1983t) en Baptism, eucharist and ministry: A liturgical appraisal of the Lima text (1986f). Hy het al verskeie kleinere monografieë die lig laat sien, waar onder die inte-ressante en gesaghebbende Christian initiation (1969, John Know Press), 'n reeks lesings oor die verhouding tussen Wesley en Calvin, Geoffrey Wainwright on Wesley and Calvin: Sources for theology, liturgy and spirituality (1987a) en twee kreatiewe ekumeniese opstelle oor die Christologie, For our salvation: Two approaches to the work of Christ (1997q). Van sy eie opstelle is gebundel in drie versamelings, te wete The ecumenical moment: Crisis and opportunity for the church (1983a), Methodists in dialogue (1995a) en Worship with one accord: Where liturgy and ecumenism embrace (1997a).

Sy invloed in Suid-Afrika is reeds wyd verbrei, in sowel kerklike as akademiese kringe. In die Woord teen die lig-reeks het hy byvoorbeeld op uitnodiging ' $n$ bydrae gelewer oor die kerklike jaar', wat ook bygedra het tot die ontluikende belangstelling in die kerklike jaar en die leesrooster in plaaslike Gereformeerde kringe. Sy invloed in plaaslike akademiese sistematies-teologiese kringe is waarskynlik veral na aanleiding van sy vroeëre werk. Met die oog daarop word aanvaar, vir die doel van hierdie bydrae, dat dié werk, tot ongeveer 1984, goed bekend is, en word slegs ingegaan op enkele van die hoofmotiewe in sy meer onlangse werk. Ook dié motiewe is nie nuut nie, maar eerder ' $n$ verdere deurvoering van idees wat strykdeur aanwesig was in sy ekumeniese benadering. Hopelik kan dié inleidende opmerkings verdere belangstelling stimuleer in die werk van hierdie besondere dogmatikus. Hy kan met reg beskryf word as die soort teoloog van wie hy self sê hulle is "interesting without being idiosyncratic"2.

Agtereenvolgens word gevra wat die visie is agter sy ekumeniese beoefening van die teologie (1), wat die motief is wat as dryfkrag dien vir 
hierdie projek (2) en wat die weg is waarop hy meen dat dit verwesenlik kan word (3).

\section{DIE VISIE: EENHEID-IN-WAARHEID}

Daar kan geen twyfel bestaan oor Wainwright se eie visie en roeping nie. Dit was reeds in sy vroeër werk glashelder en word steeds weer uitdruklik uitgespel ${ }^{3}$. Hy wil die eenheid van die kerk dien. "For all my adult life I have been engaged in the cause for Christian unity ... To the realization of that vision I devote my theological energies", verduidelik hy ${ }^{4}$.

Die verdelinge in die kerk is nie onskuldig nie, onderstreep hy telkemale. Die baie belangrike idee van "the one continuing visible and complete body of Christ", soos wat veral die Ortododokse tradisie dit leer, "challenges the insufficiency of any invisibilist, spiritualistic understanding of the Church, according to which all 'true believers' are assumed to be one, even if they live institutionally and sacramentally isolated lives ... The alternative to visible unity is not spiritual unity; it is visible disunity, which is a counter-witness to the gospel of reconciliation ... (This) should prevent Protestants from acquiescing in any (f)actual brokenness of the body of Christ. It should be a spur to efforts for the healing of the fractures that any Protestants who believe the Church to be greater than their own community are bound to recognize as afflicting a body that, on such a Protestant understanding, is in internal schism", in 'n Protestantse perspektief op die rol van die Ortodoksie in die ekumenes. Of, as hy die belang van versoening tussen verdeelde kerke bespreek: "Although it is true that institutional unity would be a mere facade without spiritual unity, it is also true that the alternative to visible unity is not spiritual unity but visible disunity. Bodies that are not seen to be united are seen to be disunited" 6 . Inderdaad, "so much of the world still remains in us that even our eucharists may be disfigured; participation in the Lord's Supper, without an authentic Christian community underlying it, becomes an exercise in make-believe, "in 'n opstel oor die nagmaal en/as etiek?.

Hierdie verdelinge weerspreek die identiteit van die kerk, beklemtoon hy telkemale. Dié identiteit word, na sy oordeel, veral in die doop en die nagmaal gekonstitueer en gedemonstreer. "The sacraments are the place where the church discovers and rediscovers its own identity", in 'n bydrae oor ' $n$ Wesleyaanse perspektief op die sakramente8. Telkens haal hy die BEM-dokument met instemming aan om hierdie punt te onderstreep. "It is in the eucharist where the church is most truly at home with God and learns to know most truly who she is" ${ }^{\prime}$. Om dié rede is die verdelinge in 
die kerk so "a sad reality". Die "normality" van die kerk word daardeur radikaal in twyfel getrek en bedreig. "The division of the churches is a counter-testimony to the Gospel of reconciliation. Severely put: the reality of the Gospel itself is called into question by disunity among Christians, and a fortiori the reality of the church which claims to have been brought into being by the Gospel. In an extreme case: can the church proclaim and transmit a gift it shows no sign of possessing? The Donatist question would re-emerge: can it truly be the Lord's baptism and supper that are being celebrated here?" 10 .

Om dié redes word versoening tussen die verdeelde kerke so dringend noodsaaklik. En dié opgaaf sluit volgens hom verskillende vorme en vlakke van versoening in, byvoorbeeld versoening ten opsigte van leerstellige en ekklesiologiese sake, soos doop, nagmaal en ampsbediening, versoening in sosiale lewe en organisasie, versoening tussen Christene, versoening tussen denominasies en tradisies, versoening binne liturgiese samekomste. Aan die tallose vrae verbonde aan al hierdie sake wy hy sy aandag oor die afgelope jare ${ }^{11}$.

Van besondere belang is sy herhaalde beklemtoning dat die eenheid sigbaar moet word. Met sigbaar bedoel hy egter nie bloot 'n vae institusionele eenheid nie, soos wat blyk uit die gedetailleerde wyses waarop hy meermale sy eie visie van die sigbare eenheid konkreet en prakties uitspel $^{12}$. Natuurlik is dit so, maak hy duidelik om enige moontlike misverstande hieroor te vermy, dat "a purely institutional unity would never be sufficient, (because) faith, hope, and charity are profound realities that exceed their visible expression", maar dit bly wel 'n onmisbare voorwaarde vir ware, voller eenheid. Juis die talle ekumeniese dialoë, in al hulle konkrete vorme, het allengs oortuigend duidelik gemaak dat daar "the need for an institutional embodiment of the Church" bestaan ('n les wat kragtig geleer is in die dialoog tussen Metodiste en Katolieke ${ }^{13}$ ), asook dat "an ecclesiology shaped in a time of division cannot be expected to be entirely satisfactory" (eweneens 'n erkenning van die Joint Commission van die Metodiste en Katolieke ${ }^{14}$ ). 'n Belangrike rede hiervoor is die sleuteltake van getuienis en opbou waartoe die kerk geroep is. Kerkordelike oorwegings en gesprekke moet daaraan ondergeskik en daartoe diensbaar wees ${ }^{15}$.

Maar waarom is hierdie versoening en sigbare eenheid tussen die verdeelde Christelike kerke so dringend noodsaaklik? Wainwright werk met 'n hele verskeidenheid van redes. Van hulle is die sending van die kerk, die roeping om die evangelie te verkondig, en gevolglik die geloofwaardigheid, die integriteit, van die kerk, van die allergrootste belang ${ }^{16}$. Hy haal graag die hoëpriesterlike gebed van Jesus volgens 
Johannes 17 aan. "The cause of unity which ecumenical dialogue subserves has, at the very least, the purpose of removing those divisions among Christians that are a counter-testimony to the gospel of reconciliation ${ }^{17}$. "Worship is intimately connected with doctrine, discipline, social organization, ethical conduct, charitable action, testimony to Christ. In all these areas, discord must give way to harmony if the Gospel of reconciliation is to be gratefully received and effectively witnessed to"18. Vir die ekumene geld dat "restoration of Christian unity was necessary not only for the practical purposes of cooperation in missionary work but, more profoundly, for the sake of a more credible witness to the Gospel of reconciliation. If the churches could not demonstrate unity among themselves, how could they testify to the reconciliation of the world to God?"19.

Van sleutel-belang in sy visie is die feit dat hierdie sigbare eenheid gebaseer moet wees op die waarheid. "We can praise God together only in truth; and this doxological unity-in-truth must take visible shape" (reeds in 1983 was dit 'n grondoortuiging van sy opstelle oor BEM²0). Sý toewyding is daarom baie doelbewus aan wat hy dikwels "classical ecumenism" noem, in bewuste onderskeid van talle ander vorme van ekumeniese strewes: "The classic modern ecumenical movement has always been concerned for unity in the truth of the gospel and the content of the faith as they come to expression in the Scriptures and in authentic Tradition"21. Sy eie jarelange betrokkenheid by die werk van Faith and Order is 'n direkte uitvloeisel en voorbeeld van hierdie soort oortuiging22 - soos ook sy uiters kritiese bydrae oor onlangse ontwikkelinge binne Faith and Order $\left.{ }^{23}\right)$. Dit geld van sy spesifieke bydrae tot $\mathrm{BEM}^{24}$, asook die bekende en omvattende Apostolic Faith Study ${ }^{25}$, sowel as van sy jare van betrokkenheid by verskillende bi- en multilaterale dialoë. Hy beskryf die Apostolic Faith Study as gebaseer op "the entire concern for authentic Christian unity in the truth of the gospel"26. Dit is waarom dogmatiese oorweginge so krities belangrik is, argumenteer hy. Wedersydse erkenning en versoening is onmoontlik sonder 'n genoegsame mate van ooreenstemming.

Wainwright gebruik 'n ganse veelvoud van uitdrukkings om die vrae rakende waarheid, normatiwiteit, en kriteria telkens weer aan die orde te stel ${ }^{27}$. Dit is absoluut duidelik dat dit vir hom van die allergrootste belang is dat die teologie en die kerk, in alle ekumeniese toenadering, sal bly vra na die waarheid, die norm, die kern, die identiteit van die Christelike tradisie en geloof. Natuurlik is al hierdie uitdrukkings omstrede en al hierdie onderskeidings hoogs problematies. In hulleself bied hulle nie maklike antwoorde aan nie, maar dien eerder as aanduidinge van 'n wesenlike problematiek. Wat "doctrine" was vir die Calviniste, sê hy, het 
Wesley afgemaak as "opinion"! (in 'n baie helder bydrae oor die Protestantse versekerdheid van die geloof en Katolieke onfeilbaarheidsopvattinge ${ }^{28}$. Dis inderdaad so dat "The precise distribution of particular items between essential doctrine and variable opinion is itself open to debate" 29 . Hy wy daarom dikwels besprekings aan die bekende debatte oor die onderskeid tussen "fundamental agreements" en "basic differences" (byvoorbeeld oor die vraag of die Reformasie al verby is; oor Lindbeck; en oor kerklike identiteit), die onderskeid tussen "centre" en "periphery", asook die belangrikheid van "'n hermeneutiek van die dogma" 30 . By al hierdie erkenning van debatte en omstredenheid, bly ag hy tog die soeke na geloofsinhoude wat "should remain self-identical to the one divine Truth kept by the Church and existing outside and beyond history" as onopgeeflik ${ }^{31}$. Miskien, erken hy, is hierdie klem op waarheid by hom deels die gevolg van wat hy beskryf as "the Methodist principle of doctrinal responsibility": Wesley se eie ruimhartigheid ten opsigte van teologiese "opinions", herinner hy graag, was steeds beperk tot dié soort menings "that did not strike at the root of Christianity" ${ }^{32}$. Wesley se bekende preek oor sy "Catholic Spirit", wat Wainwright herhaaldelik analiseer en benut, adem dus nie slegs 'n ruime, genadige en verdraagsame gees nie, maar affirmeer tegelyk ook "catholic substance" 33 . "To speak the truth in love" is sowel 'n Pauliniese as 'n Wesleyaanse motto vir dialoog, vind Wainwright, en hy ag albei elemente daarvan as baie belangrik ${ }^{34}$.

Dit is in hierdie gees dat hy kritiese waardering het vir die benaderings van twee bekende ekumeniese sistematiese teoloë, te wete George Lindbeck met sy siening van leerstellinge as grammatika en Dietrich Ritschl se benutting van die idee van "implisiete aksiomas" 35 . Dit is presies ook vanweë hierdie oortuigings aangaande die belangrikheid van waarheid, normatiwiteit en trou binne die Christelike tradisie dat hy so uitgesproke krities is teenoor wat hy dikwels met 'n sambreelterm tipeer as "liberal Protestantism"36, teenoor sekere vorme en gestaltes van postmodernisme ${ }^{37}$, en teenoor 'n verskeidenheid van onlangse inisiatiewe om nuwe Godstaal te skep $^{38}$, ten spyte van sy merkwaardige openheid teenoor die wydste verskeidenheid van posisies, standpunte en bewegings. Nie alles is aanvaarbaar nie. Hy voel so sterk hieroor dat hy meermale waarsku dat die kerk vandag nuwe vorme van apostasie in die gesig staar, en dat die waarheid van die evangelie, soos bely in die oud-kerklike Trinitariese belydenisse, vandag weer op die spel is ${ }^{39}$. Hy ag "a pure unbounded pluralism that assumes the various positions to be either incommensurable or all without epistemic significance or salutary importance" as in stryd met egte, klassieke ekumenisme ${ }^{40}$. Sy oortuiging is baie duidelik: "Agreement "in the faith' is required for visible unity ${ }^{41}$. 
Waar word hierdie waarheid egter gevind? Hy fokus herhaaldelik uitdruklik en indringend op hierdie vraagkompleks. Vroeër, sê hy, was dit bekend as die vraag na die gesag(sbronne) binne die teologie, teenswoordig word dit meesal die vraag na die sogenaamde bronne van die teologie genoem. Na sy oordeel is daar vier sulke gesagsinstansies of bronne, te wete die Skrifte, tradisie, ervaring en die rede ${ }^{42}$. Al vier hierdie instansies behandel hy in detail.

Sy groot respek vir die Skrifte blyk telkemale baie duidelik, alhoewel hy geensins naïef is wat betref die probleme wat opgeroep word deur verantwoordelike Skrifuitleg nie ${ }^{43}$. Hy heg klaarblyklik groot waarde aan die feit dat Wesley homself ook beskryf het as "a man of one Book", alhoewel hy herhaaldelik opmerk dat dié opmerking verstaan moet word as aanduiding van "not so much the boundary of his reading as the center of gravity in his thinking" - in 'n uiters interessante bydrae oor die verhoudinge tussen bid en werk by die Metodiste en die Benediktyne ${ }^{44}$.

Sy waardering vir die Christelike Tradisie is uiteraard besonder interessant. Soos wat gebruiklik is in die klassieke ekumene onderskei hy doelbewus tussen Tradisie met 'n hoofletter en tradisies met kleinletters. Hy bied ' $n$ versigtige en informatiewe bespreking van wat hy noem "the carriers, patterns, functions and limitations of traditions", terdeë bewus daarvan dat konfessionele trou maklik kan omslaan in tradisionalisme, wat die kerk verdeel en bestaande verdelinge bevestig ${ }^{45}$. Hy bepleit meer doelbewuste teologiese besinning oor die aard van tradisie, en veral aan "the maintenance of the Church in the apostolic faith" ${ }^{46}$.

Hy bespreek ook die ander twee bronne van onderskeidelik ervaring ${ }^{47}$, waarby die probleemkomplekse van kultuur en kontekstualiteit ingesluit is ${ }^{48}$ - wat hy bedink met behulp van die nuttige konsep van 'n "assimilative tradition" - asook van redelikheid ${ }^{49}$ meermale en uitvoerig, maar maak baie duidelik dat dit juis in hierdie twee areas is waar "the challenge of modernity is usually first encountered", sodat dit dan telkens weer noodsaaklik word om terug te gaan "to look at Scripture and tradition, for those are the inherited resources upon which Christianity must draw if it is to retain its historic identity" 50.

Die vier gesagsbronne speel dus elk 'n rol, maar moet elkeen sorgvuldig en versigtig bedink en verstaan word, en hulle is sekerlik ook nie op 'n gelyke vlak nie, sodat hulle onderlinge samehange en wedersydse beïnvloeding ewen-eens bewustelik in ag geneem moet word.

Kortom, alhoewel hy sekerlik nie 'n eenvoudige of naïewe antwoord op die vraag na die waarheid voorstaan nie, is hy ook nie bereid om die idee prys te gee nie. Hy bly toegewy aan die visie van Christelike identi- 
teit, hoe problematies dit ook al mag wees - reeds in Doxology het hy dit die onderliggende tema van sy dogmatiek genoem ${ }^{51}$. Dit roep om die uiters moeilike, maar nie onmoontlike, taak van onderskeidings2.

\section{DIE MOTIEF: OM TOT LOF VAN GOD TE WEES}

Maar waarom is hierdie soeke na sigbare eenheid, gebaseer op die waarheid van die evangelie, so belangrik? Weer eens is Wainwright se eie antwoorde op hierdie vraag voor-die-hand-liggend. Omdat ons geroepe is om tot lof van die Drie-enige God te wees, saam met, ja, as deel van die ganse skepping53. Ons hele bestaan is "towards God" (die titel van sy intreerede by Union), "ad majorem Dei gloriam" (die titel van sy huldiging aan Barth) ${ }^{54}$. Dit is waarom lofprysing, "doxology" (die titel van sy dogmatiek) so belangrik is, en waarom, volgens hom, "it is no accident that the twentieth-century liturgical and ecumenical movements have gone hand in hand" 55 .

Sy uiteindelike visie is een van Worship with one accord (die titel van sy onlangse bundel opstelle). Die aanbidding van die kerk noem hy herhaaldelik die lokus van alle teologie. Teologie is gevolglik vir hom "kerklike nadenke"56. Die kerk is in die eerste plek 'n aanbiddende gemeenskap57. Aanbidding ag hy 'n primêre aktiwiteit van die kerk, wat geen verdere regverdiging nodig het nie, en liturgie en kerkleer is ten nouste met mekaar verbonde 58 .

Hierdie punt moet egter selfs nog duideliker gestel word. Die finale bedoelinge is nie bloot net dat ons God met die hart en mond loof nie, maar dat ons tot lof van God is ${ }^{59}$. Aanbidding, leer en lewe behoort onlosmaaklik tesame. "Common confession of the faith is needed for united worship, life and mission. Made both before God and before humankind, coram Deo and coram hominibus, confession is at once doxological, evangelistic, and ethical, in intention and scope ${ }^{60}$. Herhaaldelik verwys Wainwright met klaarblyklike instemming na die Ortodokse opvatting aangaande 'n "liturgy after the Liturgy". Alhoewel hy nie dikwels en uitvoerig oor etiek (of politiek) skryf nie ${ }^{61}$, kan daar hoegenaamd geen twyfel wees oor die fundamentele belang van hierdie verhoudinge binne sy teologie nie. Die verhouding tussen leer en etiek ag hy van so 'n aard dat dit goed moontlik is om 'n dogmatiek vanuit die perspektief van die etiek te skryf, op soortgelyke wyse as wat hy dit vanuit die perspektief van die liturgie onderneem het ${ }^{62}$. "Thus the lex orandi and the lex credendi remain incomplete without a corresponding lex bene operandi ${ }^{63}$.

Die verhouding tussen aanbidding en etiek word gevolglik herhaaldelik binne sy werk onderstreep ${ }^{64}$. "Our delight and our duty" is ten nouste 
met mekaar verweef, al is dit op hoogs komplekse maniere ${ }^{65}$. Gebed en werk behoort tesame, as "the works of piety" en "the works of mercy" onderskeidelik ${ }^{66}$. Hoe meer sigbaar die vrugte van die Gees is, destemeer oortuigend is die prediking en onderrig van die kerk, sê hy67. Die "euchological and the ethical are subsumed in a single doxology" 68 . "'Right worship' can only occur where Christians are united in faith and life"69. Omgekeerd geld ook dat "corporate worship" die ruimte en geleentheid is "where the lives and belief of the Christian people are shaped" 70 .

Dit is in besonder die nagmaal wat dien as paradigma van die Christelike lewe en etiek, vir ons "discernment and action". In die baie belangrike opstel "Eucharist and/as ethics" behandel hy hierdie samehange uitvoerig. Die nagmaal "allows us to learn, absorb, and extend the values of God's kingdom ... The eucharistic paradigm points us in the right direction (of justice, peace, and joy): it sets the vector within which the difficult concrete decisions and actions of everyday life have to be taken and performed if they are to be authentically Christian; it excludes the choices which fall out of the range indicated by the values of the kingdom there expressed in symbolic form" 71 .

Hy haal graag die BEM-dokument aan om hierdie integrale verbande tussen sakrament en etiek op kragtige maniere te demonstreer. "Our common baptism constitutes a call to the churches to overcome their divisions and visibly manifest their fellowship"72. "The inability of the churches ... has given dramatic visibility to the broken witness of the Church. The readiness of the churches in some places and times to allow differences of sex, race, or social status to divide the body of Christ has further called into question genuine baptismal unity of the Christian community (Gal 3:27-28) and has seriously compromised its witness ${ }^{73}$.

Ten opsigte van die nagmaal is sake selfs nog dringender. "Insofar as Christians cannot unite in full fellowship around the same table to eat the same loaf and drink from the same cup, their missionary witness is weakened ${ }^{74}$. Ons eie verlossing kan daarmee in die gedrang kom, dui hy aan. "The eucharistic celebration demands reconciliation and sharing among all those regarded as brothers and sisters in the one family of God and is a constant challenge in the search for appropriate relationships in social, economic, and political life ... All kinds of injustice, separation and lack of freedom are radically challenged when we share in the body and blood of Christ ... The eucharist shows that our behaviour is inconsistent in face of the reconciling presence of God in human history: we are placed under continual judgment by the persistence of unjust relationships of all 
kinds in our society, the manifold divisions on account of human pride, material interest and power politics and, above all, the obstinacy of unjustifiable confessional oppositions within the body of Christ ${ }^{75}$. 'n Vroeëre konsep van BEM, sê hy, het gelui ons gebrek aan versoening "makes a mockery" van die nagmaal76.

Die Faith and Order-studie oor die Belydenis van Nicea openbaar ook hierdie "strong awareness that the apostolic faith has to be explicated in relation to the challenges - perennial and contemporary - that it faces", omdat "doctrinal affirmations (should) relate to ethical problems. Thus the project is linked to other ecumenical concerns for peace, justice, and the integrity of creation" 77 .

\section{DIE WEG: SPIRITUALITEIT, AANBIDDING, BELYDENIS}

Maar hoe kan hierdie visie van die sigbare kerk, gebaseer op die waarheid, wat die Drie-enige God loof deur sy vieringe, sy strukture en sy getransformeerde lewe verwesenlik word, konkreet en daadwerklik bereik word?

Die antwoord op hierdie vraag kan nie so maklik soos die vorige twee uit Wainwright se werk afgelei word nie. In 'n sekere sin het al sy werk te doen met die soeke na diverse antwoorde op dié vraag. 'n Mens kan egter ten minste drie fundamentele oortuigings uitlig wat wel behulpsaam kan wees in die soeke na dié antwoorde. Dit is geleë in sy beskrywing van 'n ekumeniese spiritualiteit, sy erkenning dat daar 'n effektiewe werking uitgaan van gemeenskaplike aanbidding en sy voorstelle vir die beofening van onderlinge en wedersydse belydenis en vergiffenis.

(a) Eerstens. Sy bekende opstel oor ekumeniese spiritualiteit in The study of spirituality (1986a) is van fundamentele belang. "The spirituality of the ecumenical movement has been, perhaps above all, a spirituality of meeting", verduidelik hy. Hy haal uit die sogenaamde "testament" van die invloedryke Cardinal Mercier aan om dié soort spiritualiteit mee te demonstreer: "In order to unite with one another, we must love one another; in order to love one another, we must know one another; in order to know one another, we must go and meet one another". Hoe vind dit konkreet plaas? Op tallose wyses, maak hy duidelik. Deur praktyke soos gebede vir mekaar, en dan (later, hopelik) saam met mekaar, deur vriendskapsbeoefening, deur gesamentlike dienste en gesamentlike dienslewering, deur gemengde huwelike tussen gelowiges uit verskillende tradisies, deur informele assosiasie en samewerking, deur gesamentlike Bybelstudie, deur sending, noodleniging, inter-kerklike hulp en ondersteuning, om saam te vat, deur allerlei vorme van koinonia ${ }^{78}$. In al hierdie uiteenlopende vorme 
van ontmoeting speel dialoog 'n onontbeerlike rol as ekumeniese instrument 79 . Dié dialoog begin dikwels met "strangers beginning to meet" 80 .

Wainwright beskryf vyf - wat hy noem - "conditions of travel on the voyage towards unity" wat in hierdie dialoë en vorme van samewerking belangrik is. Hulle is agtereenvolgens "choice of companions" (dit is onmoontlik om die ongemaklike en vreemde gespreksgenote ewig te vermy), die aanvaarding van "different starting points" (want almal begin eenvoudig nie op dieselfde plek en met enerse opvattings en gebruike nie), die "search for a common language" (sodat begrip wel moontlik kan word), die voortdurende "re-reading (of) the guides" (te wete die Skrifte en Tradisie) en die soeke na geskikte samewerking tussen "ships that pass in the night" (oor die verskillende modelle en verwagtinge van eenheid wat mag bestaan) ${ }^{81}$.

In sy eie bydraes tot bilaterale en multilaterale dialoë - soos wat dit byvoorbeeld uitvoerig gedokumenteer word in die twee bundels Methodists in dialogue en Worship with one accord - openbaar Wainwright werklik 'n uitson-derlike vermoë "to look in different directions at the same time", om uiteenlopende standpunte te respekteer en om, indien enigsins moontlik, altyd tegelyk vanuit die diverse perspektiewe te argumenteer en te dink $^{82}$. Hy benadruk dat dit altyd noodsaaklik is om die "mutual suspicion" met groot erns te bejeën ${ }^{83}$ en dat, "to understand a controversy, it is often helpful to see what each party fears about the implications and consequences of the other's position ${ }^{84}$. Van hierdie soort spiritualiteit was hy dikwels 'n lewende voorbeeld85.

Hy herinner ook sy hoorders en lesers dikwels aan die voorrang van liefde bo waarheid. Hy haal graag John Wesley se bekende Letter to a Roman Catholic instemmend aan en pleit vir "a dialogue of truth" en "a dialogue of love" om mekaar wedersyds te informeer en te bevrug86. Wat werklik nodig is in die verdeelde kerk is "the profounder process of reception", wat meer insluit as maar net die aanvaarding van dokumente, tekste en besluite, te wete ook die leiding en die implikasies van hierdie gesamentlike denke "for worship, educational, ethical, and spiritual life and witness". Uiteindelik gaan dit om die aanvaarding van mense, van gelowiges, van mekaar, van diegene ágter die dokumente en die tekste ${ }^{87}$.

(b) Tweedens. Veral in sy vroeër werk het Wainwright veel daarvan gemaak dat 'n baie spesifieke vorm van ontmoeting, te wete dié van gemeenskaplike en tussen-kerklike aanbidding, nie slegs 'n sigbare getuienis is aangaande die mate van eenheid wat reeds bereik is nie, maar self ook 'n wesenlike en kreatiewe bydrae kan mak tot meerdere eenheid. Gesamentlike en gemeenskaplike aanbidding is ' $n$ instrument op die weg van bereiking van die visie van ware Christelike eenheid88. 
Dit is - nog - een van die maniere waarop die oud-kerklike beginsel van lex orandi-lex credendi, waarvan Wainwright veel maak, ook kan funksioneer. Gelowiges wat saam aanbid, al is dit slegs by geleentheid, kan in die proses nader groei aan mekaar. In sy latere werk word hy meer terughoudend rondom hierdie moontlikheid 89 en plaas hy self meer klem op die rol van gesamentlike aanbidding om die mate van eenheid wat reeds bereik is sigbaar te maak, alhoewel hy tog steeds gebruik maak - al klink dit soms eklekties en ietwat terughoudend - van kontemporêre sosiale teorieë om daaraan te herinner dat "worship practices should - in the delicate relationship between signifying what is already the case and effecting what is still to be - both reflect the existing degree of unity and further it" ${ }^{\text {90. }}$.

(c) Derdens. In verskillende onlangse artikels het Wainwright konkrete en baie leersame voorstelle gemaak rakende onderlinge en wedersydse belydenis van skuld en gesamentlike vieringe van vergiffenis met die oog op situasies waar daar verdeling, skeuring en konflik tussen kerke en gelowiges is. In dié proses stel hy 'n hele reeks brandende vrae aan die orde, bied hy 'n rykdom aan inspirerende en aangrypende aanhalings uit die kerk- en liturgiegeskiedenis (bv van Pous Paulus VI, Ekumeniese Patriarg Athenagoras I en Pous Johannes Paulus II) en maak hy 'n hele reeks insiggewende voorstelle en opmerkings.

Só bied hy byvoorbeeld ook liturgiese voorstelle vir eredienste van versoening, "when the dogmatic conditions have been satisfied". Juis wanneer ons te make kry met die vraag hoe "a constitutive service of reconciliation between divided Christian communities" sou kon plaasvind, sê hy tereg, word "profound ecclesiologial presuppositions" blootgelê. Hy verwys onder andere na fundamentele vrae soos: Kan "'n kerk" berou hê en belydenis doen? Wie kan in sulke gevalle namens die kerk praat? Is alle partye in sodanige konflikte ewe skuldig en verantwoordelik - "for faults rarely if ever reside with a single party", sê hy? ${ }^{91}$. Wie bely en wie skenk die vergiffenis? Hoe kan die genesing, wat so noodsaaklik is (want "schism dismembers the body of Christ ... divisions inflict wounds on the body ... Christian disunity is a sickness of the body, and even chronic illnesses can be life- threatening"), plaasvind? Hoe vind die allernoodsaaklike "reconciliation of memories" plaas?

Ook in dié verband onderstreep hy dat enige ooreenkoms op die basis van die waarheid moet geskied. "The churches have indeed begun to show regret, and even express penitence, for the divisions among Christians, but they will not be ready to enact reconciliation among themselves unless and until they have managed to settle those matters pertaining to the 
truth of the Gospel that have hitherto - either as the cause or as the effect of a division - been considered church-dividing". En 'n wesenlike deel van die ekumeniese strewe is juis is "to discern what unity in faith, order, and life is necessary and sufficient for eucharistic communion" 92 .

\section{Afsluitend}

Vanselfsprekend verdien die korpus en die kwaliteit van Geoffrey Wainwright se teologiese bydrae veel indringender analise en kommentaar as wat in hierdie kort bydrae moontlik is. Hopelik het hierdie bondige opmerkings egter reeds belangstelling gestimuleer in die werk van een van dié Christelike teoloë van die twintigste eeu.

Oor die relevansie van sy werk vir die gefragmenteerde kerke en vir teologie-beoefening in Suid-Afrika hoef sekerlik nie veel gesê te word nie. Hopelik is die Russies-Ortodokse spreuk waarvoor hy so lief is, dat "the walls of separation do not reach up to heaven" inderdaad waar ${ }^{93}$. En hopelik breek die dag aan dat Suid-Afrikaanse Christene ook die liturgie van versoening, wat hy voorstel, met mekaar vier, ad majorem Dei gloriam.

Met reg herinner, waarsku, hy: "We are not so naïve as to think that the hard work of study, writing, and negotiation, necessary as these are, will of themselves achieve the desired unity of Christians in a single fellowship of worship and mission". Om dié rede bly die verlangende en volhardende gebed noodsaaklik: "for Christian unity and for the world to which the Gospel is to be preached"94.

\section{Wainwright se werk geraadpleeg}

1979. "In praise of God", Worship 53, 496-511.

1980a. Doxology. The praise of God in worship, doctrine, and life. New York: Oxford University Press.

1980b. Ordination rites past and present, with W Vos. Rotterdam: The Liturgical Ecumenical Center.

1981a. "Towards God", USQR, Vol XXXVI: 13-26.

1981b. Eucharist and eschatology. New York: Oxford University Press.

1982a. "Der Gottesdienst als Locus Theologicus, oder: Der Gottesdienst als Quelle und Thema der Theologie". KuD 1982, 4: 248-257.

1982b. "Systematic theologies written and unwritten", Epworth Review, January 1982, 87-92.

1982c. Liturgical time, with W Vos. Rotterdam: The Liturgical Ecumenical Center.

1983a. The ecumenical moment: Crisis and opportunity for the church. Grand Rapids:

Wm B Eerdmans.

1983b. "The ecumenical moment", in 1983a, 1-18.

1983c. "Church and Spirit", in 1983a, 19-30.

1983d. "Baptism and unity", in 1983a, 31-53.

1983e. "Eucharist, reconciliation, and renewal", in 1983a, 54-72. 
1983f. "Eucharist and conciliarity", in 1983a, 73-94.

1983g. "Ordained ministry", in 1983a, 95-119.

1983h. "Sacramental time", in 1983a, 120-133.

1983i. "Between God and world", in 1983a, 134-149.

1983j. "Revolution and quietism", in 1983a, 150-168.

1983k. "Mary and methodism", in 1983a, 169-188.

19831. "Ecclesial location and ecumenical vocation", in 1983a, 189-221.

$1983 \mathrm{~m}$. "Reconciliation in ministry", in: M Thurian (ed), Ecumenical perspectives on baptism, eucharist and ministry. Geneva: WCC, 129-139.

1983n. "Eschatology", in G S Wakefield (ed), A dictionary of christian spirituality. London: SCM Press = The Westminster dictionary of christian spirituality. Philadelphia: Westminster Press, 135-137.

1983o. "Adoration", in A Richardson and J Bowden (eds), A new dictionary of christian theology. London: SCM Press = The Westminster dictionary of christian spirituality. Philadelphia: Westminster Press, 6.

1983p. "Preaching as worship", Greek Orthodox Theological Review 28, 325-336.

1983q. "Proclamation", in A Richardson and J Bowden (eds), A new dictionary of christian theology. London: SCM Press = The Westminster dictionary of christian spirituality. Philadelphia: Westminster Press, 470f.

1983r. "The sermon and the liturgy", Greek Orthodox Theological Review 28, 337349.

1983s. "Sanctification", in A Richardson and J Bowden (eds), A new dictionary of christian theology. London: SCM Press = The Westminster dictionary of christian spirituality. Philadelphia: Westminster Press, 521.

1983t. Baptism and Eucharist: Ecumenical convergence in celebration, co-editor, Geneva: WCC.

1984a. "Reception of 'baptism, eucharist and ministry' and the apostolic faith study", Journal of ecumenical studies 21, 71-82, and in J Gros (ed), The search for visible unity: Baptism, eucharist, ministry, New York: Pilgrim Press, 71-82.

1984b. "Is the Reformation over?" TSF Bulletin, May-June 1984, 2-5.

1985a. "The praise of God in the theological reflection of the church", Interpretation $39,34-45$.

1985b. "Theology as churchly reflection", in T W Jennings (ed), The vocation of the theologian. Philadelphia: Fortress press, 9-24.

1985c. "Gottesdienst: systematisch-theologisch", in Theologische Realenzyklopädie. Berlin: De Gruyter, vol 14, 85-93.

1986a. The study of spirituality, with Jones, C \& Yarnold E (eds). New York: Oxford University Press.

1986b. "Ad majorem Dei gloriam", in McKim, D K (ed), How Karl Barth changed my mind, Grand Rapids, Wm B Eerdmans, 178-181.

1986c. "Theology of worship", in 1986a, 505-507.

1986d. "Types of spirituality", in 1986a, 592-605.

1986e. "Ecumenical spirituality", in 1986a, 540-548.

1986f. "Baptism, Eucharist and Ministry: A liturgical appraisal of the Lima text, coeditor, Geneva: WCC.

1987a. Geoffrey Wainwright on Wesley and Calvin: Sources for theology, liturgy and spirituality. Melbourne (Australia): Uniting Church Press. 
1987b. "Confession of fault and reconciliation between the churches", in M Collins and D Power (eds), The fate of confession = Concilium No 190, 117- 126.

1987c. "Ecumenical dimensions of George Lindbeck's "Nature of doctrine', in Modern theology 4, 121-132.

1987d. "Christian spirituality", in M Eliade (ed), Encyclopedia of Religion, New York: Macmillan, vol 3, 452-460.

1988a. "Christian doctrine / Systematic theology", in P Avis (ed), The threshold of theology. Basingstoke (Hants): Marshall Pickering, 54-84.

1988b. Keeping the faith: Essays to mark the centenary of 'Lux Mundi'. Philadelphia: Fortress Press, and London: SPCK Press, 1989.

1988c. "Preaching around the calendar", in C W Burger et al (eds), Sermon guidelines for preaching in Easter, Ascension, and Pentecost, Grand Rapids: Wm B Eerdmans, 112.

1988d. "Pannenberg's ecumenism", in C E Braaten \& P Clayton (eds), The theology of Wolfhart Pannenberg, Minneapolis: Augsburg, 207-223.

1990a. "Die Kraft des Zeichens: Sakrale Symbole in der modernen Welt", Evangelische Kommentare 23, 461-465.

1990b. "Bemerkungen aus Amerika zu Dietrich Ritschls 'Logik der Theologie'”, in W Huber and others (eds), Implizite Axiome: Tiefstrukturen des Denkens und Handelns. Dietrich Ritschl gewidmet. Munich: Kaiser, 218-228.

1990c. "Doctrine, liturgy and", in Peter E Fink (ed), The new dictionary of sacramental worship. Collegeville: Liturgical Press, 349-358.

1991a. "The doctrine of the Trinity: Where the church stands or falls" in Interpretation 45, 117-132.

1991b. Dictionary of the ecumenical movement. [co-ed, with N Lossky et al]. Geneva: WCC; Grand Rapids: Eerdmans.

1991c. "Canon", in 1991b, 115-118.

1991d. "Church", in 1991b, 159-167.

1991e. "Methodist-Reformed dialogue", in 1991b, 672-673.

1991f. "Dialogue, multilateral”, in 1991b, 291-293.

1991g. "Eucharist", in 1991b, 374-377.

1991h. "Scripture", in 1991b, 909.

1991i. "Intercommunion", in 1991b, 518-520.

1991j. "Lex orandi, lex credendi", in 1991b, 600-604.

1992a The study of liturgy with Jones, C and Yarnold, E (eds), London: SPCK, and New York: Oxford UP.

1992b. "The continuing tradition of the church", in 1992a, 547-562.

1993a. "Faith and Order within or without the World Council of Churches" in Ecumenical Review 45, 118-121.

1993b. "Holiness" in B M Metzger and M D Coogan (eds), The Oxford companion to the Bible. New York and Oxford: Oxford University Press, $285 \mathrm{f}$.

1993c. "Worship" in B M Metzger and M D Coogan (eds), The Oxford companion to the Bible. New York and Oxford: Oxford University Press, 819f.

1993d. "Liturgy and doctrine" in A E McGrath (ed), The Blackwell Encyclopedia of modern Christian thought. Oxford: Blackwell, 339-344.

1993e. "Method in theology" in A E McGrath (ed), The Blackwell Encyclopedia of modern Christian thought. Oxford: Blackwell, 369-373. 
1904. "Church and sacrament(s)" in J B Webster (ed), The possibilities of theology: Studies in the theology of Eberhard Jüngel in his sixtieth year. Edinburgh: $\mathrm{T} \& \mathrm{~T}$ Clark, 90-105.

1995a. Methodists in dialogue. Nashville: Abingdon Press.

1995b. "Methodists in dialogue", in 1995a, 13-36.

1995c. "Roman Catholic-Methodist dialogue: A silver jubilee", in 1995a, 37-56.

1995d. "The assurance of faith: Methodists and infallibility", in 1995a, 57-72.

1995e. "The end of all ecclesiastical order", in 1995a, 73-88.

1995f. "Ora et Labora: Benedictines and Wesleyans at prayer and at work", in 1995a, 89-108.

1995g. "Ecclesiological tendencies in Luther and Wesley", in 1995a, 109-114.

1995h. "Uniting what was never divided: The next steps for Lutherans and Methodists", in 1995a, 115-120.

1995i. "Reason and religion: A Wesleyan analogue to Grundtvig on modernity and the Christian tradition", in 1995a, 121-142.

1995j. "Perfect salvation in the teaching of Wesley and Calvin", in 1995a, 143-160.

1995k. "Tradition and the spirit of faith: Methodists address the Orthodox", in 1995a, 161-178.

19951. "The Orthodox role in the ecumenical movement: A Protestant perception", in 1995a, 179-188.

1995m. "Methodism and the Apostolic Faith", in 1995a, 189-206.

1995n. "Methodists respond to BEM", in 1995a, 207-222.

1995o. "Ecclesial identity: Basic agreements and basic differences", in 1995a, 223230.

1995p. "Doctrine, opinions, and Christian unity: A Wesleyan and Methodist perspective", in 1995a, 231-236.

1995q. "Wesley and the communion of saints", in 1995a, 237-250.

1995r. "Sent to disciple all mankind': A Wesleyan and Biblical theology of mission", in 1995a, 251-260.

1995s. "Why Wesley was a Trinitarian", in 1995a, 261-276.

1995t. "Continuing a Methodist voice", in 1995a, 277-286.

1996. "Back to the future", in Miroslav Volf and others (eds), The future of theology:

Essays in honor of Jürgen Moltmann. Grand Rapids: Eerdmans, 89-97.

1997a. Worship with one accord. New York: Oxford University Press.

1997b. "Where liturgy and ecumenism embrace", in 1997a, 1-18.

1997c. "The curch as a worshiping community", in 1997a, 19-34.

1997d. "Bible and liturgy': Daniélou's work revisited", in 1997a, 35-44.

1997e. "Tradition as a liturgical act", in 1997a, 45-64.

1997f. "The Lima text in the history of Faith and Order", in 1997a, 65-84.

1997g. "Sacramental theology and the world church", in 1997a, 85-104.

1997h. "The sacraments in Wesleyan perspective", in 1997a, 105-126

1997i. "Renewing worship: The recovery of classical patterns", in 1997a, 127-140.

1997j. "Divided by a common language? A comparison and contrast of liturgical revision in the United Kingdom, the United States of America, and Australia", in 1997a, 141-158.

1997k. "The reconciliation of divided churches: A witness to the gospel", in 1997a, 159-182. 
19971. "Reconciliation: Irish and ecumenical", in 1997a, 183-200.

1997m. "Eucharist and/as ethics", in 1997a, 201-216.

1997n. "Praying for kings: The place of human rulers in the divine plan of salvation", in 1997a, 217-236.

1997o. "Trinitarian worship", in 1997a, 237-250.

1997p. "Canons, cultures, and the ecumenically correct", in 1997a, 251-276.

1997q. For our salvation: Two approaches to the work of Christ. Grand Rapids: Eerdmans, and London: SPCK.

1997r. "The Holy Spirit", in Colin Gunton (ed), The Cambridge Companion to Christian Doctrine. Cambridge: The University Press, 273-296.

\section{NOTAS:}

1 "Preaching around the calendar", in: C W Burger et al (eds), Sermon guidelines for preaching in Easter, Ascension, and Pentecost, Grand Rapids 1988, 1-12.

2 In sy bondige, dog uitstekende inleiding tot Christelike leer en sistematiese teologie, 1998a:73. Hy het 'n besondere kennis van sistematiese teologie, sowel histories as twintigste-eeus. Hy lees 10 tale en skryf self in 'n hele paar van hulle. Enigeen wat sy gereelde oorsig-rubriek in die Expository Times oor sistematiese teologie vanaf die Europese vasteland volg, sal kan getuig van sy merkwaardige belesenheid en kritiese onderskeidingsvermoë. Daarby weet hy ewe veel van krieket! Hy het saam met spelers soos Barrington en Boycott gespeel en vertel self dat die enigste verleiding wat hom moontlik sou kon weghou van die teologie die moontlikheid sou wees om kaptein van Yorkshire and Engeland te wees 1998a:77!

3 Volgens hom is sy ekumeniese visie en passie tipies van Wesley: "A Wesleyan and a Methodist imbibes ecumenism with his mother's milk" (1995a:9). Selfs die karaktertrekke van sy werk, wat aan die orde gaan kom in hierdie bydrae, kom grootliks ooreen met sy eie samevattende beskrywing van "some Methodist principles of ecumenism", te wete "doctrinal responsibility, spiritual engagement, missionary orientation, and trinitarian doxology" (1995a:9). Vir outobiografiese besonderhede, asook vir sy eie beskrywing van die taak van teologie, sien die opstel oor teologie as kerklike refleksie, in Theodor W Jennings se bekende bundel oor die roeping van 'n teoloog, 1985b, asook die alreeds vermelde tipering van sistematiese teologie, 1988a.

4 In 'n bespreking, van sleutelbelang vir sy eie sieninge, van kanon, kultuur en ekumene, waarin hy - soos meermale - argumenteer dat egte "klassieke" ekumenisme partikulariteit wil respekteer sonder om in fragmentarisme te verval (1997:273).

5 19951. "The Orthodox role in the ecumenical movement: A Protestant perception", in 1995a, 180.

6 1997k. "The reconciliation of divided churches: A witness to the gospel", in $1997 \mathrm{a}, 178$.

$71997 \mathrm{~m}$. "Eucharist and/as ethics", in 1997a, 209.

8 1997h. "The sacraments in Wesleyan perspective", in 1997a, 106.

9 Vergelyk ook sy benutting van kragtige aanhalings van Mary Tanner, eweneens van Faith and Order, oor die eenheid van die kerk en die vernuwing van kerk en 
menslike gemeenskap, waarin sy die kerk se tekenkarakter verbind met eenheid, identiteit, Triniteit, en die nagmaal, 1997k:176 ev.

10 1997k. "The reconciliation of divided churches: A witness to the gospel", in $1997 \mathrm{a}, 164$.

11 Vir 'n vollediger bespreking, sien 1997k. Oor die afdeling in BEM wat die amp behandel merk hy op dat "regrettably the chance to use the word 'reconciliation' was lost - which is needed if the calling and task is to be fulfilled", 1997k:163. Oor bekering, vergifnis en versoening as momente binne die Christelike liturgie, sien sy behandeling van die kerk as 'n aanbiddende gemeenskap, 1997c:28-29.

12 1997c. "The church as a worshiping community", in 1997a, 24.

13 1995d. "The assurance of faith: Methodists and infallibility", in 1995a, 68.

14 1995c. "Roman Catholic-Methodist dialogue: A silver jubilee”, in 1995a, 48.

15 Sien die insiggewende artikel oor "The end of all ecclesiastical order", 1995e, 73-88: "It remains characteristic of Methodism that all Church structures ... will be tested by their contribution to communion with God and among Christians".

16 Oor die feit dat Metodiste se betrokkenheid in die ekumene deur hulle missionêre drif gemotiveer word, sien sy bespreking van Metodistiese betrokkenheid in die ekumeniese dialoë, (1995b:13), asook die baie interessante bydrae oor 'n Metodistiese perspektief op gesaghebbende leer, blote meninge en Christelike eenheid, (1995:234); Wesley se eie beskouinge "will encourage Methodists to stretch their tolerance to the limits for the sake of unity in evangelism and mission ... It is above all this missionary motivation which has prompted Methodist participation, both British and American, in the World Council of Churches, and which has pushed churches of British Methodist origin in particular in the direction of organic unity". Vergelyk ook die opstel oor Wesley se siening van die sending, (1995r:251 ev), en Wainwright se waardering vir Lesslie Newbigin, oor wie hy tans aan 'n boek werk, asook sy kommentaar op die bekende ekumeniese motiewe van die verhouding tussen die kerk as geheimenis en as profetiese teken, en die verhouding tussen die eenheid van die kerk en die vernuwing van die mensheid, (1997k:175 ev).

17 Byvoorbeeld 1995b. "Methodists in dialogue", in 1995a, 34; sien ook 1995r:251-260.

18 1997a. Worship with one accord. New York: Oxford University Press, vii-viii. 1997b:1. As hy in "Back to the future", 1996:97 die taak van die teologie in die volgende eeu beskryf, soos hy dit sien, doen hy dit as herontdekking van die getuienis van die verdeelde kerk deur liturgie, ekumenisme, dogmatiek en hermeneutiek: "In the twenty-first century, the ecumenical task will still be to identify the church. Scriptural hermeneutics will be needed to test whether the liturgical anamnesis truly proclaims the things of Christ and the liturgical anamnesis effectively produces the fruit of the Spirit. Dogmatic reflection will be needed to aid pastoral and magisterial judgment in discerning ...".

20 1983b. "The ecumenical moment", in 1983a, 3.

21 Vir 'n helder omskrywing van hierdie ideaal, sien 1997:273, waar hy uitdruklik byvoeg: "For all my adult theological life I have been engaged in the cause of Christian unity ... To the realization of that vision I devote my theological 
energies". So ook 1995b:33 en 1995t:279: "In my judgment, the ecumenical movement, and indeed the entire body of those who claim the name of Christ, is facing one large and comprehensive question ... It is the matter of maintaining, in the presence of internal and external pressures, a recognizable continuing identity with historic Christianity. Of course, Christian history itself is multiform, and divisions among those who call themselves Christian render the whole notion problematic. But a principal aim, and partial achievement, of the modern ecumenical movement has been to discern the authentic Tradition of the dominical gospel and the apostolic faith in its historically, geographically, and culturally varied manifestations".

22 Sien "The reconciliation of divided churches: A witness to the gospel", 1997k, 166-167.

23 1993a. "Faith and Order within or without the World Council of Churches" in Ecumenical Review 45, 118-121.

24 Sien die opstelle reeds in 1983a, soos byvoorbeeld 1983b (wat die ekumeniese oomblik tipeer), 1983d (oor die doop), 1983e en 1983f (oor die nagmaal) en $1983 \mathrm{~g}$ (oor die ampsbedieninge), sowel as $1983 \mathrm{~m}$ (oor versoening in die ampsbeskouinge en -praktyke), 1984a (oor die ekumeniese "resepsie" van BEM - 'n sleutelvraagstuk binne die ekumeniese beweging), $1991 \mathrm{~g}$ (oor die nagmaal) en 1991i (oor inter-kommunie), en 1995n (oor Metodistiese reaksies op BEM vanoor die hele wêreld). Daarby ook $1997 \mathrm{f}$ (oor die geskiedenis van die Limateks) en 1997g (wat BEM in verband bring met resente Katolieke denkontwikkelinge rondom die sakramentsleer).

25 1995m. "Methodism and the Apostolic Faith", in 1995a, 189-206.

26 1995b. "Methodists in dialogue", in 1995a, 18.

27 Vergelyk byvoorbeeld "fides quae creditur", "truths of the last importance", "the very heart of Christianity", "maintenance in the truth", "identity in the apostolic message", "ecclesial identity, in the senses both of character or profile and also of consistency or continuity", "proclamation of the true gospel", "a marrow of the Christian truth", "a living core", "the main branches of Christian doctrine", "evaluative criteria", "questions concerning the nature, identity, and boundaries of the Church", "substantial heritage", "the authentic Tradition", "the great tenets of the Church's belief", "indispensable criteriological concern(s) in the search for ecclesial unity" in onderskeidelik 1995d:63, 1995e:84, 1995i:123, 1993e:375, 1995n:209 ev, 221 ev, 1995o:223 ev, 1995p:233 ev, 1995t:277, 1997a:viii.

28 1995d. "The assurance of faith: Methodists and infallibility", in 1995a, 61.

29 1993e. "Method in theology" in A E McGrath (ed), The Blackwell Encyclopedia of modern Christian thought. Oxford: Blackwell, 375.

30 1984b. "Is the Reformation over?" TSF Bulletin, May-June 1984, 2-5; 1987c. "Ecumenical dimensions of George Lindbeck's 'Nature of doctrine', in Modern theology 4, 121-132; en 1995o. "Ecclesial identity: Basic agreements and basic differences", in 1995a, 223-230.

31 19951. "The Orthodox role in the ecumenical movement: A Protestant perception", in 1995a, 183.

32 1995a:9, sien ook sy bespreking in 1995p:231-236. Hierdie ruimhartigheid "should therefore not be abused in favour of sentimental ecumenism or even religious indifferentism", 1993e:375. 
33 So byvoorbeeld in 1995b:33 en 1995m:192: "Even at his most 'catholic spirited', Wesley refused his hand to Arians, semi-Arians, Socinians and Deists, for their heart was not right with his heart".

34 1995b:33. In Eucharist and eschatology het hy inderwaarheid reeds gepleit vir die voorrang van liefde bo waarheid, in die geval van "the un-ideal circumstances of a Christian disunity needing to be surmounted", $1981 \mathrm{~b}: 143 \mathrm{ev}$.

35 Oor die afgelope jare het hy telkens weer, in uiteenlopende kontekste, teruggekeer na Lindbeck se voorstelle, byvoorbeeld in 1997d:42 (oor Daniélou se blywende bydrae, onder die tema van Bybel en liturgie), 1997i:138 ('n belangrike oorsig oor die blywende, klassieke patrone van die Christelike liturgie wat behoue moet bly by alle inisiatiewe tot vernuwing), in 1997j:156 (oor liturgiese vernuwing in verskillende kontekste en kerke in die wêreld) en in 1987c, waar hy 'n uitvoerige bespreking aan Lindbeck wy. Oor Ritschl, sien byvoorbeeld 1990b, waarin hy Ritschl se bydrae vergelyk met sy eie benadering, asook dié van Tracy en Lindbeck.

$36 \mathrm{Hy}$ is uitermate krities van wat hy noem: "The persisting ideology of the American Enlightenment, which is (at most) deistic in its theological options", 1995h:117 (in 'n bydrae oor die take wat voorlê vir Lutherane en Metodiste); maar ook in $1986 \mathrm{c}$ (sy uitstekende oorsigtelike bespreking van verskillende tipes van Christelike spiritualiteit), 1995m:203 ev (oor Metodiste en die Apostoliese Geloof-projek), 1997h:105 (oor die sakramente vanuit Metodistiese perspektief), 1997j (oor liturgiese vernuwing) en 1997o:237 (in 'n baie belangrike bydrae oor Trinitariese aanbidding, wat van sy belangrikste gedagtes saamtrek).

37 Hy openbaar 'n sekere siniese huiwering om die huidige tydsgewrig as "postmodern" te tipeer: "Such acceleration in journalistic historiography is to overprivilege the ephemeral", 1995i:122 ('n interessante opstel oor modernisme, godsdiens en rasionaliteit), vergelyk ook die endnoot 3 op bladsy 312; asook 1995i:127, $130 \mathrm{ev}, 1997 \mathrm{~d}: 40$ en 1997p:251 ev.

38 Vergelyk reeds 1991a oor die Triniteitsleer as die geloofsartikel waarmee die kerk staan of val, 1995m:192-193, 1995t:279 ev. (oor die toekoms van Metodisme), 1997h:120 (oor die sakramente), 1997j:155 ev (oor liturgiese vernuwing) en 1997 o (oor Trinitariese aanbidding).

39 Hy argumenteer telkens weer dat die Trinitariese belydenis vandag weer op die spel staan, byvoorbeeld in 1995m:203: "The signs are that the doctrine of the Trinity is becoming once again, as it was in the fourth century, the articulus stantis et cadentis ecclesiae". Ook so in die reeds vermelde 1991a, 1995p:234 en 1997o:246. Weer eens beskou hy hierdie besorgdheid van hom as tipies Metodisties, sien 1995s:261-276 oor Wesley as 'n Trinitariër.

40 1995b:31. Hy het klaarblyklik simpatie met die verklaring wat Ortodokse afgevaardigdes uitgereik het na die WRK se Canberra-vergadering dat "common prayer will become increasingly difficult" sonder 'n spesifiek Christelike teologiese basis, dat "theological criteria must define the limits of diversity" en dat "the biblical faith in God must not be changed", asook met die Evangeliese Brief, by dieselfde geleentheid, wat beweer dat "discernment is necessary ... to develop criteria for and limits to theological diversity", 1995t:281 ev.

41 1995m. "Methodism and the Apostolic Faith", in 1995a, 194. 
Vergelyk die uitstekende oorsig van metodologie in die teologie in 1993e: "(This) brings to the fore the question of criteria for faith, doctrine and theology ... These are often grouped under four heads: Scripture, tradition, reason and experience. Since each of these is a different kind of thing and may exercise appropriately different functions, they may operate in various harmonious combinations. In practice, however, they sometimes assume competitive roles, especially when controversial issues in the life of the faith community need to be decided in a theologically responsible way. Certainly it is possible also to make a rough characterization of a reflective theologian's method according to the prominence and respective functions occupied by Scripture, tradition, reason and experience in his or her own work or system". In die res van sy bespreking is dit dan ook presies wat hy op 'n baie verhelderende wyse probeer doen, met die argument: "The recent and contemporary scene is confused but vital, with claims being staked for all four of the principal sources of theology ... Ecumenism at all levels, and in both the synchronic and diachronic senses, is a necessity if further fragmentation is to be avoided".

Besonder interessant is sy herhaalde opmerkings oor die wyse waarop Amerikaanse Metodiste omgegaan het met hierdie "fourfold strand", wat populêr bekend is as "the Wesleyan or Methodist quadrilateral", byvoorbeeld in 1995i:123ff; "in so far as this expression may suggest an equal authority given to all four on a level plane, it is historically and theologically misleading". Hy beklemtoon byvoorbeeld die feit dat kwalifiseerders nodig is om die uiteenlopende funksie en gesag van hierdie bronne te omskryf: "the living core of Christian truth stands revealed in scripture, illumined by tradition, vivified in personal experience, and confirmed by reason", 1995k:175 ev (oor Metodiste en die Ortodoke Kerk). Sien ook 1995n:209 ev, 1995p:236, asook 'n goeie samevattende opmerking 1995t:277.

As hy Wesley self bespreek, onderskei hy tussen ses "principal features", naamlik "the Scriptures as primary and abiding testimony, the ministry of evangelism, generous orthodoxy, sanctification, social concern, and the Lord's Supper as sacramental sign of fellowship”, 1995t:283-284.

43 "The Scriptures, not understood fundamentalistically but nevertheless taken as the Word of God, have actively remained for me the primary source of faith and theology", reeds in $1985 \mathrm{~b}: 11$, oor sy siening van die taak van teoloë. Oor die jare het gereeld gepubliseer oor temas soos die Skrifte, die kanon, hermeneutiek, interpretasie, trajekte in die Bybel, die probleme van fundamentalisme en biblisisme, ensovoorts, vergelyk byvoorbeeld 1991c en 1991h (twee woordeboek- opstelle), asook 1997d, in aanvulling tot talryke vroeëre bydraes.

44 1995f. "Ora et Labora: Benedictines and Wesleyans at prayer and at work", in 1995a, 101.

45 Vergelyk die opmerking: "Because in the sixteenth century nothing less than the truth was at stake, they quickly acquired a marked 'confessional' identity, which characterizes Lutherans to this day. If now an ecumenical consensus in faith, in all quod ad unitatem requiritur et sufficit, is coming within reach, the Lutherans too should be prepared, in the service of a unitas fratrum to be realized at local and universal levels, to surrender their purely 'denominational' structures", 1995g:114 (oor ekklesiologiese tendense by Luther en Wesley). 
Oor tradisie, sien 1992b ('n ensiklopedie-artikel oor tradisie) en 1995c:51 ev, vir ' $n$ bespreking van Tavard se konsep van die voortsetting van die apostoliese tradisie as "koinonia in time" en van die "manifold means" waardeur hierdie tradisie corgelewer en ontvang word. In meer onlangse opstelle het hy juis die liturgiese byeenkoms beskryf as "the home of both Scripture and Tradition", in die hoop dat hierdie "move" kan bydra tot 'n beter begrip van die onderlinge verhouding tussen die twee, wat so 'n sleutel- vraag vir die kerk en spesifiek vir die ekumeniese strewe is. Sien daarvoor 1997d (oor die Bybel en liturgie) en veral die baie informatiewe 1997e (oor tradisie in die liturgie, waar hy ook die hermeneutiese en normatiewe aard van die Skrifte aan die orde stel).

47 1995i:128 ev. In onlangse geskrifte het hy meermale nagedink oor die belangrikheid van al die sintuie, byvoorbeeld 1997d:42, 1997i:137 en die volledigste in die eerste opstel in $1997 \mathrm{~g}$, cor ons belewenis van die verlossing in Christus.

48 Hy was altyd geïnteresseerd in die verhoudinge tussen Christendom en kultuur. Sedert sy dae in Afrika, toe hy vanaf 1967 tot 1973 in Kameroen gewerk en gedoseer het, het hy konstruktiewe bydraes oor hierdie vraagkompleks gelewer, veral oor wat hy die "localization of worship" genoem het. Oor die wyses waarop kultuur kan bydra tot verskeidenheid in die liturgie (teenoor 'n beskuldiging van "antiquarianism in liturgy"), sien 1992b.

Sy benadering word saamgevat in die opmerking: "The trick ... must be to affirm and integrate those features of our culture that derive from Christianity and may enrich the Christian tradition, while at the same time we reject the antiChristian elements and demonstrate their wrongness. This twofold (or fourfold) procedure - of assimilation and refusal (or affirmation and integration, rejection and rebuttal) - is necessary for apologetics, evangelism and doxology, if the way is to be cleared, humanly speaking, for the grace of God to abound to more and more people and for the eucharistic chorus thereby to swell ... In each generation, this clarification, discernment, and risk of judgment may be the principal duty of reflective theology to assist the Church and its pastoral leaders", 1995i:121 ev. Die doel is dat ekumenisme "should facilitate that proclamation and embodiment of the one gospel in diverse cultural circumstances which have been the aim of Christianity ... since its beginnings", 1995m:206. Vir gedagtes oor kultuur binne die konteks van sakramentele denke, $1997 \mathrm{~g}: 86 \mathrm{ev}$.

49 Sien 1997p:264 ev vir 'n sleutel-bespreking, waarin hy pleit vir 'n religieuse kanon, maar met ruimte vir kulturele pluralisme, op sodanige wyse dat dié twee verbind word in 'n "assimilative tradition". Vir belangrike opmerkings, vergelyk ook 1997e:60-61.

50 1995i. "Reason and religion: A Wesleyan analogue to Grundtvig on modernity and the Christian tradition", in 1995a, 124. In hierdie verhouding geniet die Skrifte prioriteit. Dit geld selfs en uitdruklik ook ten opsigte van die oudkerklike belydenisse, herinner hy. "Although, historically, oral and practical tradition preceded the New Testament scriptures, and although the confession and preaching of the apostolic faith developed in parallel with the development of those scriptures, yet I judge (standing in the line of Wesley) that ancient creedal confessions and epitomes of the apostolic preaching must, theologically, 
be seen as summaries of the scriptures before they can be seen, as it were independently, as their hermeneutical key ... The thick and complex texture of the scriptures themselves keeps them resistant to truncation and allows them to go on providing a variety of resources for contemporary proclamation and confession”, 1995i:134.

Soos Faith and Order by Montreal gedoen het, verklaar hy "that Scripture is the internal norm to Tradition and Tradition the interpretive context of Scripture", maar volgens hom het Montreal daarmee nog nie die kriteriologiese vraag beantwoord nie, dog slegs nog gestel. Ons staan steeds voor "the criteriological questions that arise when it comes to discerning and expressing the truth of the Christian faith and embodying it in the life of the Church ... How, concretely, are we to distinguish failures, deviations and witherings in the Christian witness from genuine and vital testimony?", 19951:84-185. Eweneens nuttig is 1997f:73-74.

51 1980a. Doxology. The praise of God in worship, doctrine, and life. New York: Oxford University Press. 10-11.

52 Reeds in 1980:11, ook by 1995m:199-201. Dikwels is dit die geval dat "many on both sides would deny that truth was optional. In that case, there can be no reconciliation without substantive agreement, although a certain range of interpretation might eventually come to accommodate both sides", 1995a:296, noot 2 , met verwysing na $1983 \mathrm{k}$, waar hy die meningsverskille rondom die Mariologiese dogmas behandel.

53 Vir 'n uitvoerige bespreking, 1997o, en vir die Wesleyaanse bronne van dié motief, 1995s:261-276.

54 Die intreerede is gepubliseer as 1981a. Die huldiging vir Barth is in 1986a. Ook wanneer hy Calvyn bespreek is dit 'n sleutel-motief, byvoorbeeld 1987a. Oor aanbidding en sy eie teologie van aanbidding, 1983o en 1986b, 1983h (oor tydsbelewenis in die sakrament binne die aanbidding), 1985a (oor die lof van God in teologiese nadenke), 1985c ('n gesaghebbende ensiklopedie-artikel in die TRE oor erediens), 1993c (eweneens 'n ensiklopedie-artikel). Oor die aard en funksie van predking binne die liturgie, sien byvoorbeeld 1983q ('n woordeboek- artikel) asook 1983p ('n belangrike bydrae in gesprek met die Ortodoksie).

55 1997e. "Tradition as a liturgical act", in 1997a, 61, nog meer uitvoerig by $1997 \mathrm{~b}$.

56 Sien besprekings van aanbidding as lokus van die teologie in 1982a, van lof as inhoud van teologie in 1985a, en van die taak van teologie in 1985b.

57 Byvoorbeeld 1990a (oor simbole), 19990c, 1993c en 1993d (al drie oor aanbidding) en 1995c (oor Katolieke en Metodiste dialoog). Hy verdedig ' $n$ "encompassing ecclesiology that takes worship as a primary duty of the church (with witness and service)", 1997a:viii. Meer volledig in 1997c, waar hy "a normative shape and content" ontwikkel vir "the church's gathering as a liturgical community ... stretched between what is already possible ... and what is still necessary".

58 Sy teologie is ten diepste gebaseer op die komplekse onderlinge verbande tussen aanbidding en leer, die lex orandi en die lex credendi. Hy noem dit self "the heart" van Doxology, in sy insiggewende verduideliking in 1979:505. Sien ook 
uiteensettings in 1993d, en 1980, 1985a, 1986:b, 1990c, 1991j. In dié verhouding het die leer 'n besondere funksie. "The wild growths to which devotion is always susceptible may, with proper theological responsibility, be pruned and trimmed by the pastoral and teaching authorities of the church", 1993d:343. Dit was ook die benadering van die Hervormers: "The Protestant Reformers ... (who) acted in the name of the scriptures which, though they themselves were to a great extent liturgically composed, defined and transmitted, nevertheless possess a special doctrinal authority in view of their canonical status as word of God", 1990:355-356.

59 "Praise is a linguistic act with an ontological basis and consequences: 'That we may be to the praise of God's glory' is how the hymn in Ephesians 1:3-14 puts it", 1985a.

60 Reeds die subtitel van Doxology (1980a) toon dit aan. In sy later werk word dié benadering konsekwent volgehou. Sien 1995m:194, 201 ev. Of: "By combining the doxological, kerygmatic and ethical components ... the WCC project should help to hold together the varying dominant interests of particular groups: the liturgical, the evangelistic, and the social-activist", 1995m:205-206. In die voorwoord van 1997a:vii verduidelik hy die "constant themes" van hierdie versameling as volg: "Lip service of God is useless unless accompanied not only by faith in the heart (Rom 10:8-10) but also by matching deeds (Mt 7:21; Heb 13:15f.). The church's worship assembly is an expression and a school of faith; its liturgical celebration enacts, in ritual mode, the love toward God and neighbor in which true religion consists ... Worship is intimately connected with doctrine, discipline, social organization, ethical conduct, charitable action, testimony to Christ". Of vergelyk 1997c:31: "The emphasis on leitourgia is not to deny the importance of martyria and diakonia - the church as a 'witnessing community' and a 'caring community'"

61 Uitsonderinge is die betrokke hoofstukke in Doxology, sowel as 1983i en 1983j, twee sleutel-opstelle in The ecumenical moment, asook die resente $1997 \mathrm{~m}$ en 1997n (oor voorbidding vir die staat), twee ewe belangrike opstelle in Worship with one accord.

62 Hy het by geleentheid gespekuleer of Keith Ward 'n sistematiese teologie sou skryf vanuit 'n etiese hoek, 1982b:92, 'n interessante klassifikasie van sistematiese teologieë.

63 1991j. "Lex orandi, lex credendi”, in 1991b, 604.

64 Weer eens is Wesley 'n belangrike inspirasie vir hom. Vergelyk sy bekende uitsprake "Christianity is essentially a social religion" en "there is no holiness but social holiness", sowel as sy sieninge van die beeld van God (geestelik, polities en moreel), asook sy eie merkwaardige voorbeeld, 1995f:90 ev. Wat Lutherane sou bejeën as "moralism", sou hy eerder wou sien as "ethical seriousness": "Wesley saw it to be Methodism's providential call to 'spread scriptural holiness through the land", 1995g:112. "We need to rediscover the Wesleyan fusion of confession coram Deo and coram hominibus", 1995m:194. "Orthodoxy was, for Wesley, not so much unnecessary as insufficient - if it was not believed, experienced, and lived", 1995m:195. Vir Wesley se siening van heiligheid, sien 1995q:245 ev.

In hierdie verband toon Wainwright ook waardering vir Calvyn se opvattinge oor heiligmaking en heiligheid, sien 1987a, 1993b, 1983s, en beskou hy Barth 
se analogie-leer as "the best account of the proper relation of the Christian community to the civil community", 1997n:234, noot 50.

Hy benut ook telkens Niebuhr se bekende tipologie uit Christ and Culture. Meesal argumenteer hy dat elke posisie 'n mate van geldigheid besit (behalwe vir "the abysmal second type"), maar soms gee hy voorkeur aan die vyfde tipe, as die een "with the most to commend it", byvoorbeeld 1997g:100,1997m:229, 1983n, 1986c.

65 1985a. "The praise of God in the theological reflection of the church", Interpretation 39, 34-45, maar ook in 1997c:22, en, versigtig en genuanseerd, in $1997 \mathrm{~m}$.

66 1995f. "Ora et Labora: Benedictines and Wesleyans at prayer and at work", in 1995a, 89-108.

67 "Since, in God, truth and love are one, it may be assumed that true teaching is best conducive to love, while love will give insight into the truth of God. Loving reconciliation among Christians is itself an attempt at conformity to truth, and the process may be expected to bring us closer not only to one another but to God", 1995d:63-64. "Preaching is indirectly doxological in that it is an encouragement to doxological living”, 1983p:329.

68 1995f. "Ora et Labora: Benedictines and Wesleyans at prayer and at work", in $1995 \mathrm{a}, 99$.

69 1997b. "Where liturgy and ecumenism embrace", in 1997a, 1.

70 Dit beskou hy as die "the pastoral concern" agter die strewe van die moderne liturgiese beweging "to recover the classical substance and forms of Christian worship", 1997i:127 ev.

71 1997m. "Eucharist and/as ethics”, in 1997a, $210 \mathrm{ev.}$

72 Baptism, par 6, in Baptism, Eucharist, Ministry, 1982.

73 Baptism, commentary par 6, in Baptism, Eucharist, Ministry, 1982.

74 Eucharist, par 26, in Baptism, Eucharist, Ministry, 1982.

75 Eucharist, par 20, in Baptism, Eucharist, Ministry, 1982.

76 1997k. "The reconciliation of divided churches: A witness to the gospel", in $1997 \mathrm{a}, 163$.

77 1995m. "Methodism and the Apostolic Faith", in 1995a, 194.

78 1986e. "Ecumenical spirituality", in 1986a, 540-548, ook 1986c en 1987d.

79 1995b. "Methodists in dialogue", in 1995a, 13.

80 1995h. "Uniting what was never divided: The next steps for Lutherans and Methodists”, in 1995a, 115-120.

81 1997f. "The Lima text in the history of Faith and Order", in 1997a, 69-75.

82 Sien byvoorbeeld die retoriese strategieë wat hy benut in sy bydraes tot die Metodiste-Katolieke dialoog (1995d:57-72), die Metodiste-Lutherse dialoog (1995h:115-120), die Metodiste-Ortodokse dialoog (1995k:161-178 en 19951:179- 188), of die Metodiste-Gereformeerde dialoog (1995j:143-160). Vir teoretiese opmerkings oor ekumeniese dialoë, 1995b:31-32. Oor multilaterale dialoë, ook $1991 \mathrm{f}$.

83 1995d. "The assurance of faith: Methodists and infallibility", in 1995a, $57 \mathrm{ev.}$

84 1995j. "Perfect salvation in the teaching of Wesley and Calvin", in 1995a, 157 ev.

$85 \mathrm{Al}$ sê hy self dat hy soms "inadequate empathy" openbaar. En al is die beste wat hy by geleentheid van Lutheranisme kan sê dat hulle "a necessary critical 
irritant" is!, 1985b:12. "It is the permanent Lutheran task to warn others against exaggerating that grain of truth which the great Tradition at least secretly allows to Pelagianism", 1995g:111.

86 1995b:13. Hierdie brief "can set an example for the conduct of ecumenical dialogue in at least three ways", meen hy, naamlik in "the human, and Christian respect and concern" teenoor gespreksgenote, in die "methodological and hermeneutical principle" om te onderskei tussen "vital doctrines and opinions", en in die "openness to other traditions" en die "treasures that have been better preserved, insights that have been more vitally lived, in other parts of the great Christian Tradition than their own", 1995m:201.

87 1997f. "The Lima text in the history of Faith and Order", in 1997a, 80, ook 1984a, oor resepsie.

88 Reeds in Doxology en The ecumenical moment (bv $90 \mathrm{ev}$ ). In die algemeen geld: "theologians of ecumenism seized the opportunity to treat worship as both a means and an end to the restoration or achievement of Christian unity", 1993d:342.

89 In 1997k: 177 ev onderskei hy tussen "four broad positions”: “(1) I myself now reject a totally 'open communion', allegedly practiced on missionary grounds ... The identity of the celebrating church has to be preserved. (2) I also reject promiscuous intercommunion among individual Christians or the separate communities to which they belong; for that is to minimize the gravity of unrepented continuing divisions ... (3) In my opinion, however, there do come points at which, short of the achievement of the envisaged full unity towards which they are praying and working, ecclesial communities that are converging in faith, order and life may practice intercommunion. They will do so both in order to celebrate the measure of unity already reached and in order to gain strength for future progress. (4) Nevertheless, I respect the stricter view that no eucharistic communion should be enjoyed before some kind of qualitatively complete unity in faith, order and life has already been attained".

In 1998d:214, as hy Pannenberg se ekumenisme bespreek, sê hy: "I myself used to take such a "productive" view of intercommunion, but I have become much more hesitant ... For my part, I am suspicious of the current doctrinal indifferentism and institutional minimalism. For doctrine and institution come close to faith and order, which are integral to Christianity. Eucharistically, I am concerned for the identity of the celebrating community and therefore of the message it is proclaiming".

90 1997a:viii. Sien 1997d:36 ev oor "the modalities - linguistic, symbolic, institutional - by which the history (of Jesus Christ) is 'told', 'prolonged', and 'entered into'". Ook 1997f:79, 1997g:87 ev, 1997i:137-138, en vir meer volledige behandelinge, 1990a en 1997j.

91 "But who is the offending party? ... Certainly, hindsight usually reveals that the fault in any division - even though truth may have been at stake in a matter of doctrinal conflict - did not reside on one side alone. Even though one side rather than the other may somehow be 'proved right' in a matter of faith, the responsibility for the disruption will usually have been complex - and shared", 19971:192.

92 Veral drie van sy opstelle werp lig op hierdie saak. In 'n eerste opstel, 1987c, behandel hy sake rakende "the confession of guilt and reconciliation between 
the churches". In 'n tweede, 1997k, wat op die vorige bou, fokus hy weer eens op moontlikhede vir die "reconciliation of divided churches as a witness to the gospel”. In 'n derde bydrae, 19971, bespreek hy die tema van ekumeniese versoening spesifiek met verwysing na die Ierse konflik.

In die eerste vra hy twee ekklesiologiese vrae. Die eerste is "when faced by the evil mystery of collective or corporate division among Christians, can that be regarded as sin against the church 'as such', since that will have implications for any possible confession of fault?". Die tweede vraag is of skism slegs mense ván die kerk kan skei, of ook mense van mekaar bínne die kerk self? As eersgenoemde die geval is, is die enigste uitweg 'n "ecumenism of return", maar indien die tweede die geval kan wees, moet die heling plaasvind as 'n innerlike proses binne die kerk self. In dié gees behandel hy dan uitvoerig 'n aantal konkrete voorstelle tot versoening tussen verdeelde kerke, te wete "recognising the presence of Christian faith in the others, acknowledging the gravity of the disunity as an offence against the grace of the gospel, the act of reconciliation itself, including careful distinctions and proposals, and finally enjoying the fruits of repentance, forgiveness and reconciliation in a shared eucharist".

In die tweede opstel beskryf hy die "sad reality" van verdeeldheid in die kerk, "contradicting the creeds, liturgies and sacraments of Christianity", en gaan dan weer eens in op praktiese voorstelle tot genesing en heling.

In die derde dink hy na oor 'n moontlike "process of reconciliation" met suggesties vir stappe van bekering, versoening en uiteindelik gemeenskap. Oor die Ierse konteks merk hy op: "One can (not) ignore social, cultural, psychological, economic, and political differences and conflicts - what were, at an earlier stage in the modern ecumenical movement, exaggeratedly called "non-theological factors". My thesis, however, is that faith, sacraments, and ecclesiology engage human life at a more fundamental and decisive level ... They set us directly coram Deo. The divine revelation and redemption told in the canonical Christian story provide a framework in which penultimate differences can be discussed; and, as progress is made in reconciliation in matters of faith, sacraments, and church, there emerges a hope for the resolution of those other conflicts in a gospel light. In other words, my bet is that water, bread, and wine are more potent symbols than sashes, berets, and flags. Hands lifted in prayer or laid on heads in forgiveness and healing are closer to reality than hands that plant bombs or squeeze triggers. The kiss of peace is more significant that a political pact, for which, however, it may lay the ground. If these things are not the case, then ultimately we are all losers", 19971:196-197.

93 Volgens hom het die Franse Katolieke ekumeniese pionier Couturier graag dié motto aangehaal, 1995q:249 (oor Wesley en die gemeenskap van die heiliges).

94 1997b. "Where liturgy and ecumenism embrace”, in 1997a, 14. 